Nevşehir Bilim ve Teknoloji Dergisi Cilt 6(ICAFOF 2017 Özel Sayı) 149-162 2017

DOI: 10.17100/nevbiltek.336203

URL: http://dx.doi.org/10.17100/nevbiltek.336203

\title{
Bilecik -Osmaneli İlçesi İçme ve Kullanma Sularının Kalite Parametreleri Açısından Coğrafi Bilgi Sistemleri (CBS) ile Değerlendirilmesi
}

\author{
M. Cüneyt Bağdatl1 ${ }^{1}$, Erkan Kalıpc1 ${ }^{2, *}$, Güneş Gonca İpek ${ }^{2}$ \\ ${ }^{1}$ Nevşehir Hacı Bektaş Veli Üniversitesi, Biyosistem Mühendisliği Bölümü̈, Nevşehir \\ ${ }^{2}$ Nevşehir Hacı Bektaş Veli Üniversitesi, Çevre Mühendisliği Bölümü, Nevşehir
}

Öz

Bu çalışma; Bilecik Osmaneli ilçesinde içme ve kullanma sularının uygunluğunun değerlendirilmesi amacıyla gerçekleştirilmiştir. Çalışmada, Bursa Valiliği İl Halk Sağlığı Müdürlüğü tarafından Bilecik Osmaneli ilçesinden 9 ayrı bölgede (Selçik, Kızılöz, Ciciler, Ericek, Çerkeşli, Oğulpaşa, Adliye, Ağlan, Sarıyazı) bulunan camiler ve köy kahvelerinden alınan su numunelerinin (içme ve kullanma suları) Halk Sağlığı Laboratuarında yapılan analiz sonuçlarının ( $\mathrm{pH}$, iletkenlik, oksitlenebilirlik, amonyum, florür, nitrit, nitrat, klorür, sülfat, selenyum, arsenik, alüminyum, bor, civa, demir, krom, kurşun, mangan, nikel, sodyum) 'İnsani Tüketim Amaçı ıular Hakkında Yönetmeliğe’ göre değerlendirmesi yapılmıştır. Verilerin dağılışı ve haritalandırılması Arc GIS 10.3.1 paket programı destekli olarak CBS ortamında Spline entelpolasyon yaklaşımı ile yapılmıştır. Su numunelerinin analizlerinin değerlendirilmesi sonucu; Osmaneli ilçesinde bulunan bütün köylerin içme kullanma suyundaki pH değerleri 6.5-9.5 değerleri arasında, İletkenlik değerleri $2500 \mu \mathrm{S} / \mathrm{cm}$ 'den düşük, Oksitlenebilirlik değerleri $5 \mathrm{mg} / \mathrm{L}$ 'den küçük, Amonyum değerleri 0,03 mg/L, Florür değerleri 1,5 mg/ L'den küçük, Nitrit değerleri 0,03 Nitrat değerleri $50 \mathrm{mg} / \mathrm{L}$ 'in altında, Klorür değerleri $250 \mathrm{mg} / \mathrm{L}$ 'den düşük, Sülfat değerleri $250 \mathrm{mg} / \mathrm{L}$ 'den küçük, Selenyum değerleri $4 \mu \mathrm{g} / \mathrm{L}$, Arsenik değerleri $10 \mu \mathrm{g} / \mathrm{L}$ değerinin altında, Alüminyum değerleri $200 \mu \mathrm{g} / \mathrm{L}$ değerinden düşük, Bor değerleri 1mg/L'den daha düşük, Civa değerleri 1 g/L, Demir değerleri $1 \mu \mathrm{g} / \mathrm{L}$, Krom değerleri $50 \mu \mathrm{g} \mathrm{L}^{-1}$ değerinin altında, Kurşun değerleri $2 \mu \mathrm{g} / \mathrm{L}$, Mangan değerleri $50 \mu \mathrm{g} / \mathrm{L}$ değerinden düşük, Nikel değerleri $20 \mu \mathrm{g} / \mathrm{L}$ değerinde düşük, Sodyum değerleri $200 \mathrm{mg} / \mathrm{L}$ değerinden düşüktür. Osmaneli ilçesinde bulunan köylerin içme ve kullanma sularındaki değerlerin tümünün yönetmelikteki değerlerin altında yer almasından dolayı 'İnsani Tüketim Amaçlı Sular Hakkında Yönetmeliğe' göre uygun değerlerde olduğu tespit edilmiştir.

Anahtar Kelimeler: Su Kalitesi, İ̧̧me ve Kullanma Suyu, Coğrafi Bilgi Sistemleri, Bilecik.

\section{Evaluation of Drinking and Domestic Water Through Quality Parameter by Geography Information Sytems (GIS) in Bilecik-Osmaneli Province}

\begin{abstract}
In the study, according to the Provincial Public Health Directorate of Bursa Governorate from Bilecik-Osmaneli district, water samples (drinking and domestic water) on the date of 20.11.2013 in 9 different regions were taken from the glasses and village cafes in the villages. As a result of the evaluation of the analysis on water samples taken from 9 different regions in the drinking and domestic waters of Osmaneli Province in 2013, the following findings are obtained; the $\mathrm{pH}$ values in drinking water of all the villagers in the province of Osmaneli are between 6.5-9.5, the conductivity values are lower than $2500 \mu \mathrm{S} / \mathrm{cm}$, oxidizable values were found to be $5 \mathrm{mg} / \mathrm{L}$, ammonium values of $0.03 \mathrm{mg} / \mathrm{L}$, fluoride values of less than $1.5 \mathrm{mg} / \mathrm{L}$, nitrite values of 0.03 , nitrate values of less than $50 \mathrm{mg}$ / L, chloride values of less than $250 \mathrm{mg}$ / L, sulphate values of $250 \mathrm{mg} / \mathrm{L}$ ' is small, selenium values of 4 $\mu \mathrm{g} / \mathrm{L}$, arsenic values of less than $10 \mu \mathrm{g} / \mathrm{L}$, aluminum values of less than $200 \mu \mathrm{g} / \mathrm{L}$, boron values of less than $1 \mathrm{mg} / \mathrm{L}$, mercury values of $1 \mu \mathrm{g} / \mathrm{L}$, iron values below $50 \mu \mathrm{g} / \mathrm{L}$, lead values $2 \mu \mathrm{g} / \mathrm{L}$, manganese values lower than $50 \mu \mathrm{g} / \mathrm{L}$, nickel values lower than $20 \mu \mathrm{g}$ / L, sodium values lower than $200 \mathrm{mg}$ / L. It has been determined that the values are in accordance with the Regulation.
\end{abstract}

Keywords: Water Quality, Drinking and Domestic Water, GIS Mapping, Bilecik.

*e-mail: ekalipci@nevsehir.edu.tr 


\section{Giriş}

Dünya üzerinde tatlı su kaynaklarının gün geçtikçe yetersiz kalması ve artan nüfus, suların daha dikkatli ve titiz kullanılmasını gerektirmektedir. Su insanlar tarafından; tarım arazilerinin sulanması, içme suyu ve su ürünleri yetiştiriciliği gibi faaliyetlerde kullanılmaktadır. İnsanların yaşamını direkt etkileyen suyun varlığının yanında kalitesi de önem teşkil etmektedir. Son zamanlarda su kalitesi araştırmaları artmıştır. Günümüzde, su kaynaklarının değerlendirilmesi, geliştirilmesi ve modern tarıma yönlendirilmesi için ülkemizde, baraj gölleri ve göletleri yapılmaktadır [1]. Sularda meydana gelen kirlenmeyi ve etkilerini belirleme çalışmalarında su kalitesinin fiziksel ve kimyasal açıdan değerlendirilmesi suyun o anki durumu hakkında bilgi vermesi açısından oldukça önem taşımaktadır [2,3]. Gerek göl, gölet ve akarsularda gerekse de denizlerde ve tarla balıkçıllğı̆nda suyun amaca uygun olup olmadığı, fiziksel ve kimyasal parametrelerin iyi bir şekilde analiz edilmesiyle mümkündür [4].

Kirlilik unsurlarında görülen artış, su kaynaklarının kalitesinin belirlenmesine ve değerlendirilmesine yönelik çalışmaların yapılmasını gerekli kılmıştır [5]. Zira günümüzde bilgisayar destekli veri analizi ve görselleştirme araçları, su kaynaklarının korunması, geliştirilmesi ve yönetimi çalışmalarında önemli rol oynamaktadır [6].

Yeryüzünde doğal ve kültürel değişimlerinin araştırılması ile öğrenilmesi amacıyla kullanılan oldukça hızlı ve doğru bilgilerin elde edilebildiği yazılımlar ve sistemler mevcuttur. Son derece karmaşık yapılara sahip bu sistemlerden periyodik olarak yeryüzüne ilişkin ve milyonlarla ifade edilebilecek veriler elde edilmektedir. $\mathrm{Bu}$ veriler teknolojik gelişmenin önemli bir sonucudur. Bu veri organizasyonunu sağlayacak sistem ise CBS 'dir. CBS, doğal ve kültürel arazi kaynaklarının en ideal kullanımını belirlemeye yardımcı olan ve arazi kaynak planlamasını başarılı şekilde yapan bir sistemdir [7]. CBS farklı formattaki birçok coğrafi verinin grafiksel ve nesnel özellikleri ile birlikte ortak bir koordinat sisteminde katmanlar şeklinde toplanması, işlenmesi, sorgulanması, analiz edilmesi ve sunulmasını olanaklı kılan bir sistemdir. Kullanım alanı son derece geniş olan CBS, bu özelliği ile farklı bilim disiplini uzmanlarının birlikte çalışması yolunda etkin bir rol oynayan önemli bir bilişim sistemi olmuştur. Farklı bilim disiplinlerinin bir arada çalışmasını olanaklı kılan CBS yazılımlarında veri toplama ve sunma dışında etkin analiz teknikleri kolay kullanılabilir hale getirilmiştir. Coğrafi bilgi sistemi ve uzaktan algılama teknolojileri geniş alanlarda yüzey suları ile ilgili olarak konumlandırma ve su kalitesi analizi çalışmalarında önemli olanaklar sunmaktadır [8].

Yapılan bu çalışma ile; İl Sağlık Müdürlüğü tarafından 2013 yılında Osmaneli'nin çeşitli bölgelerinden alınan su numunelerinin (içme ve kullanma suları) Bursa Halk Sağlığı Laboratuarında yapılan analiz $(\mathrm{pH}$, iletkenlik, oksitlenebilirlik, amonyum florür, nitrit, nitrat, klorür, sülfat, selenyum, arsenik, alüminyum, bor, civa, demir, krom, kurşun, mangan, nikel, sodyum) sonuçlarının, 'İnsani Tüketim Amaçlı Sular Hakkında Yönetmeliğe' göre incelenmesiyle elde edilen bulgular Coğrafi Bilgi sistemleri ortamında Arc MAP yazılımının Spatial analiz modülü kullanılarak mekânsal olarak değerlendirilmiştir.

\section{Materyal ve Metot}

Çalışma alanı olarak seçilen Osmaneli İlçesi; Marmara bölgesinde yer almakta olup, Bilecik iline bağlıdır (Şekil 2.1). Yüzölçümü $490 \mathrm{~km}^{2}$ alan olup, alan olarak Türkiye'nin 573. en büyük ilçesidir. 
Osmaneli ilçesi 40 21' 30.2328" Kuzey ve 30 0' 48.2364" Doğu koordinatlarındadır. Bilecik iline 24 kilometre mesafe uzaklıktadır. Osmaneli ilçesinin rakımı 110 metredir [9]. Bilecik İli Osmaneli İlçesinden 20.11.2013 tarihinde 9 ayrı bölgeden (Selçik, Kızılöz, Ciciler, Ericek, Çerkeşli, Oğulpaşa, Adliye, Ağlan, Sarıyazı) alınan su numunelerinin (içme ve kullanma suları) Halk Sağlığı Laboratuvarında yapılan analizleri (pH, iletkenlik, oksitlenebilirlik, amonyum, florür, nitrit, nitrat, klorür, sülfat, selenyum, arsenik, alüminyum, bor, civa, demir, krom, kurşun, mangan, nikel, sodyum) sonucunda 'İnsani Tüketim Amaçlı Sular Hakkında Yönetmeliğe’ göre değerlendirmesi yapılmıştır.

Verilerin dağılışı ve haritalandırılması ArcMap 10.3.1 paket programı destekli olarak CBS ortamında Spatial analiz modülü kullanılarak yapılmıştır. Google Earth Pro'dan yüksek çözünürlüklü, metrik koordinat sistemine bağlı WGS84 - Zone 36 koordinat düzleminden alınan JPEG formatındaki uydu görüntüsü ArcMAP ortamına aktarılmıştır. JPEG formatındaki uydu görüntüsünden faydalanılarak Bilecik-Osmaneli alanı ve belirlenen ölçüm noktaları sayısallaştırılarak vektör veri haline getirilmiş ve çalışma alanının sınırları elde edilmiştir. Çalışmada su örneklerinin alındığı noktaların Osmaneli ilçesi sınırlarına göre mekânsal dağılımları Şekil 2.2’de verilmiştir.

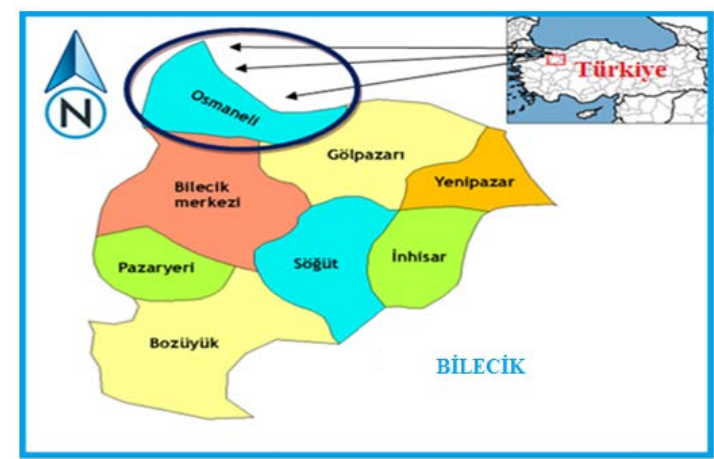

Şekil 2.1. Çalışma alanının yeri ve konumu.

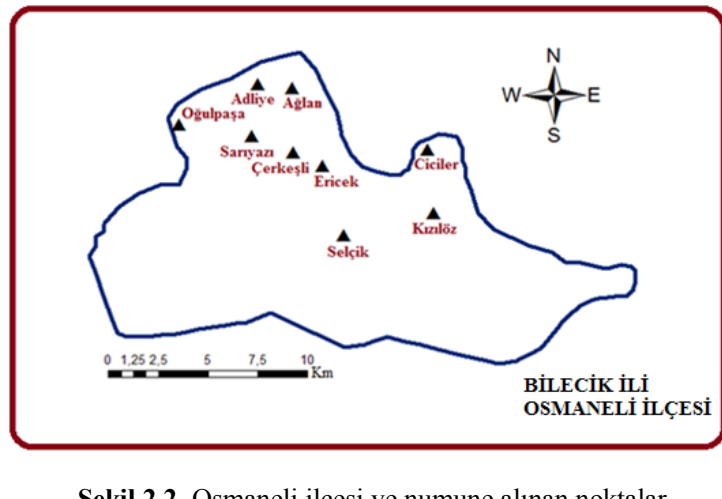

Şekil 2.2. Osmaneli ilçesi ve numune alınan noktalar.

\section{Bulgular}

Bilecik ilinde 9 farklı bölgeden alınan su numunelerinin $\mathrm{pH}$, İletkenlik, Oksitlenebilirlik, Amonyum, Florür, Nitrit, Nitrat, Klorür, Sülfat, Selenyum, Arsenik, Alüminyum, Bor, Civa, Demir, Krom, Kurşun, Mangan, Nikel, Sodyum değerlerinin Arc MAP ortamında yapılan mekânsal analiz sonuçlarında oluşturulan dağılım haritaları aşağıda verilmiştir.

\section{1. $\quad$ pH Değerlerinin Analizi}

Bilecik ili Osmaneli ilçesinde içme ve kullanma suyunda 20.11.2013 yılında 9 ayrı bölgeden (Selçik, Kızılöz, Ciciler, Ericek, Çerkeşli, Oğulpaşa, Adliye, Ağlan, Sarıyazı) alınan su numunelerindeki pH değerleri Şekil 3.1.'de verilmiştir. pH içeriklerinin mekansal dağılımı ise Şekil 3.2'de verilmiştir. Şekil 3.1. ve Şekil 3.2'de görüldüğü üzere; pH değerlerinin analiz sonuçlarına göre Osmaneli ilçesinin kuzey batı kesimindeki köylerde en yüksek değere rastlanmıştır. İç ve orta kısımlarda pH değerleri nispeten daha düşüktür. 


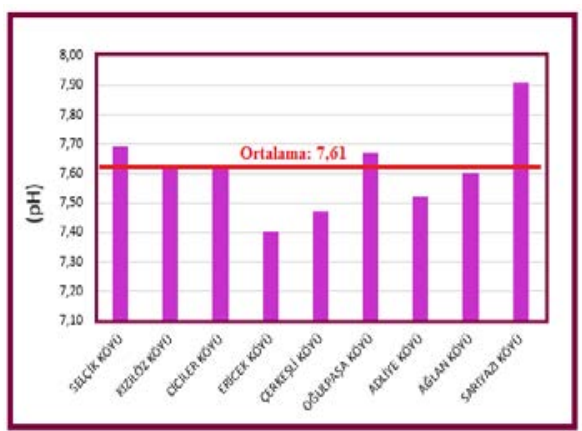

Şekil 3.1. Numune alınan yerlere göre $\mathrm{pH}$ değerleri.

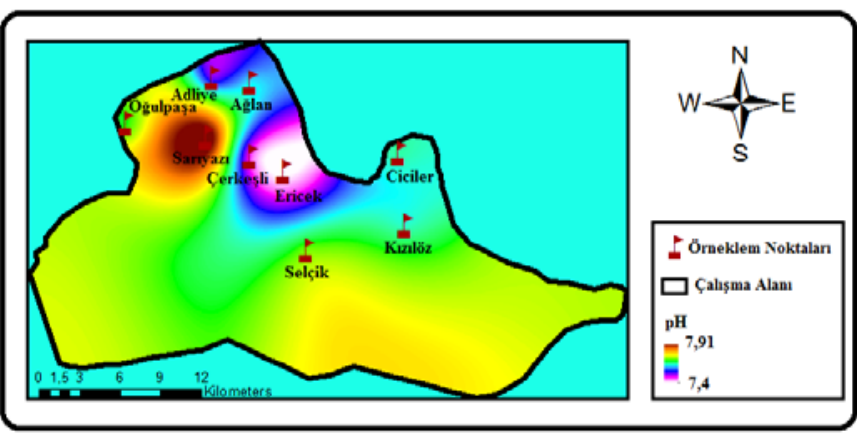

Şekil 3.2. pH içeriklerinin mekânsal dağılımı.

\section{2. $\quad$ EC Değerlerinin Analizi}

Bilecik ili Osmaneli ilçesinde içme ve kullanma suyunda 20.11.2013 yılında 9 ayrı bölgeden (Selçik, Kızılöz, Ciciler, Ericek, Çerkeşli, Oğulpaşa, Adliye, Ağlan, Sarıyazı) alınan su numunelerindeki İletkenlik değerleri Şekil 3.3.'te verilmiştir.

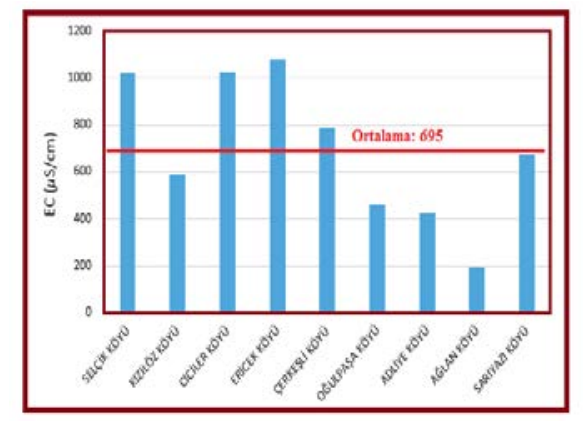

Şekil 3.3. Numune alınan yerlere göre EC değerleri.

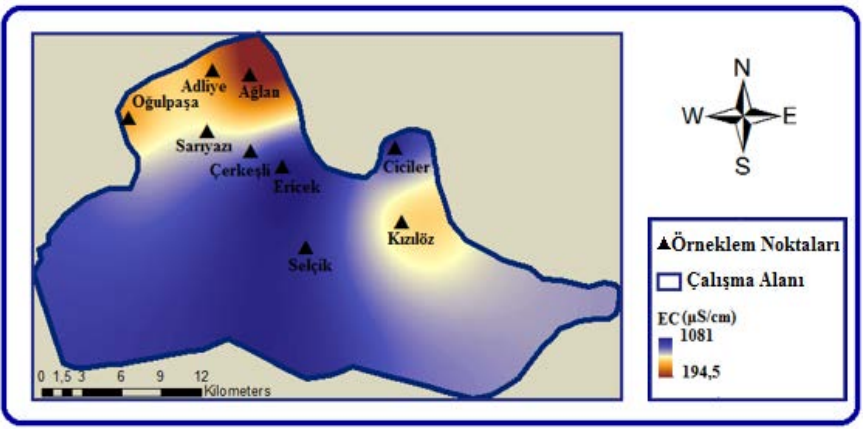

Şekil 3.4. İletkenlik içeriklerinin mekânsal dağılımı.

Şekil 3.3.'te verildiği üzere en yüksek İletkenlik değerine Ericek Köyü’nün suyunda, en düşük İletkenlik değerine ise Ağlan Köyü'nün suyunda rastlanmıştır. Osmaneli ilçesinde bulunan bütün köylerin içme ve kullanma sularındaki İletkenlik değerleri 'İnsani Tüketim Amaçlı Sular Hakkındaki Yönetmeliğe’ göre, $2500 \mu \mathrm{S} / \mathrm{cm}$ 'den düşük olduğu için uygundur. Araştırma kapsamında değerlendirilen köylerdeki içme ve kullanma sularındaki İletkenlik içeriklerinin mekânsal olarak dağılımı Şekil 3.4.'te verilmiş̧ir. İletkenlik değerlerinin analiz sonuçlarına göre Osmaneli ilçesinin kuzey kesimlerinde iletkenlik değerleri düşükken, iç ve güney kesimlere doğru daha yüksektir.

\subsection{Oksitlenebilirlik Değerlerinin Analizi}

Bilecik ili Osmaneli ilçesinde içme ve kullanma suyunda 20.11.2013 yıllnda 9 ayrı bölgeden (Selçik, Kızılöz, Ciciler, Ericek, Çerkeşli, Oğulpaşa, Adliye, Ağlan, Sarıyazı) alınan su numunelerindeki Oksitlenebilirlik değerleri Şekil 3.5.'te verilmiştir. Şekil 3.5. incelendiğinde en yüksek Oksitlenebilirlik değerine Oğulpaşa Köyü’nün suyunda, en düşük Oksitlenebilirlik değerine ise Adliye Köyü’nün suyunda rastlanmıştır. Osmaneli ilçesinde bulunan bütün köylerin içme ve kullanma suyundaki Oksitlenebilirlik değerleri 5 mg/L'den küçük olduğu için ‘'̇nsani Tüketim Amaçlı Sular Hakkındaki Yönetmeliğe’ göre uygundur. Araştırma kapsamında değerlendirilen köylerdeki içme ve kullanma sularındaki 
Oksitlenebilirlik içeriklerinin mekânsal olarak dağılımı Şekil 3.6'da verilmiştir. Oksitlenebilirlik değerlerinin analizi sonucunda Osmaneli ilçesinde orta ve doğu kısımlardaki oksitlenebilirlik değerleri kısmen daha düşükken, kuzey batıda özellikle Oğulpaşa köyünde oksitlenebilirlik değeri daha yüksektir.

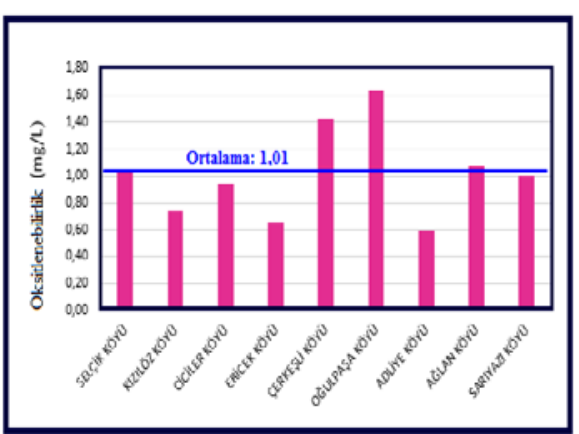

Şekil 3.5. Oksitlenebilirlik değerleri.

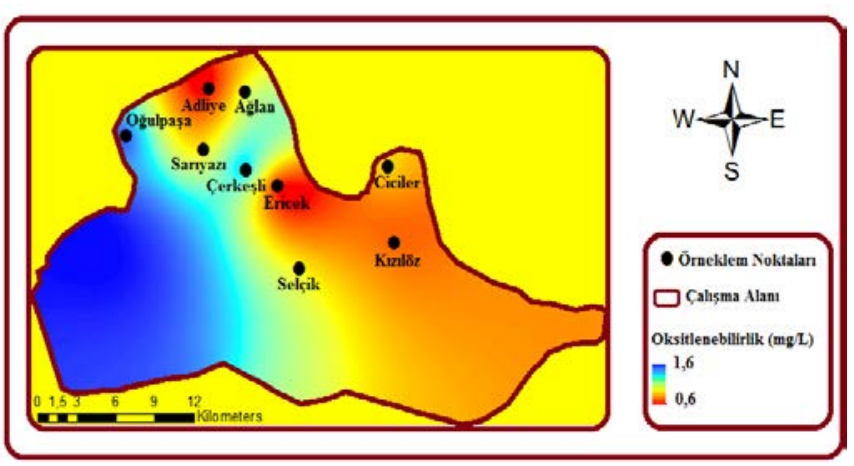

Şekil 3.6. Oksitlenebilirlik içeriklerinin mekânsal dağılımı.

\subsection{Amonyum Değerlerinin Analizi}

Osmaneli ilçesinde bulunan bütün köylerin içme ve kullanma suyundaki Amonyum değerleri 0,03 mg/L ve ‘İnsani Tüketim Amaçlı Sular Hakkındaki Yönetmeliğe’ göre 0,50 mg /L'den düşük olduğu için uygundur. Tüm değerlerin $0,03 \mathrm{mg} / \mathrm{L}$ olmasından dolayı CBS'de haritalama yapılamamıştır.

\subsection{Florür Değerlerinin Analizi}

Bilecik ili Osmaneli ilçesinde içme ve kullanma suyunda 20.11.2013 yılında 9 ayrı bölgeden (Selçik, Kızılöz, Ciciler, Ericek, Çerkeşli, Oğulpaşa, Adliye, Ağlan, Sarıyazı) alınan su numunelerindeki Florür değerleri Şekil 3.7.'de verilmiş̧ir.

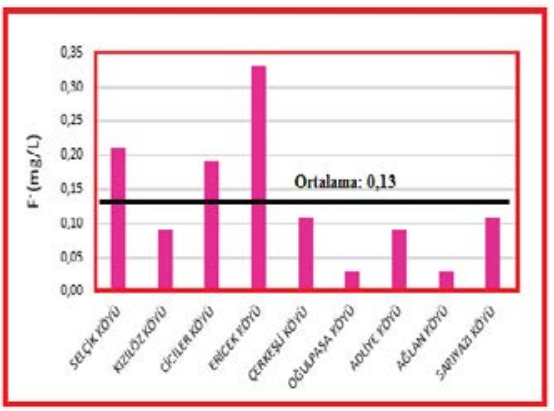

Şekil 3.7. Numune alınan yerlere göre florür değerleri.

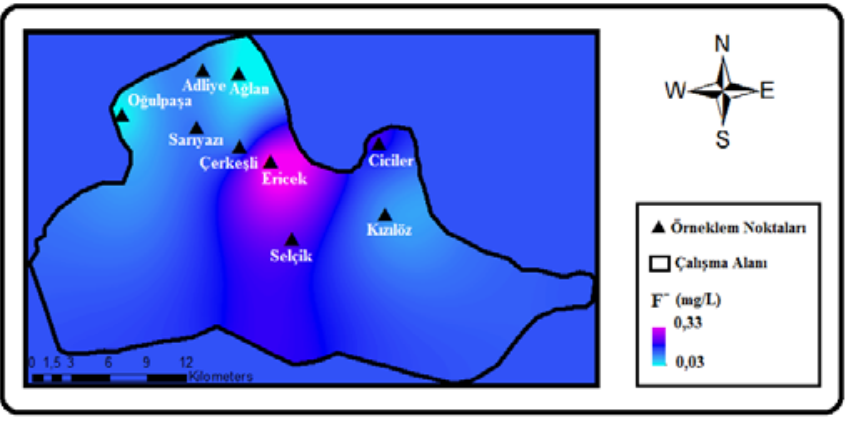

Şekil 3.8. Florür içeriklerinin mekânsal dağılımı.

Şekil 3.7’ye göre yüksek Florür değerine Ericek Köyü'nün suyunda, en düşük Florür değerine ise Ağlan Köyü’nün suyunda rastlanmıştır. Osmaneli ilçesinde bulunan bütün köylerin içme ve kullanma suyundaki Florür değerleri 'İnsani Tüketim Amaçlı Sular Hakkındaki Yönetmeliğe’ göre 1,5 mg/L'den küçük olduğu için uygundur. Araştırma kapsamında değerlendirilen köylerdeki içme ve kullanma sularındaki florür içeriklerinin mekânsal olarak dağılımı Şekil 3.8'de verilmiştir. Florür değerlerinin analizi sonucunda Osmaneli ilçesinin orta kısımlarında bulunan Ericek köyünde değerler daha yüksekken diğer kısımlarda nispeten daha düşüktür. 


\subsection{Nitrit Değerlerinin Analizi}

Osmaneli ilçesinde bulunan bütün köylerin Nitrit değerleri 0,03 mg/L ve ‘İnsani Tüketim Amaçlı Sular Hakkındaki Yönetmeliğe' göre $0,50 \mathrm{mg} / \mathrm{L}$ 'den düşük olduğundan uygundur. Tüm değerler 0.03 mg/L olduğundan dolayı CBS'de haritalaması yapılamamıştır.

\subsection{Nitrat Değerlerinin Analizi}

Bilecik ili Osmaneli ilçesinde içme ve kullanma suyunda 20.11.2013 yılında 9 ayrı bölgeden (Selçik, Kızılöz, Ciciler, Ericek, Çerkeşli, Oğulpaşa, Adliye, Ağlan, Sarıyazı) alınan su numunelerindeki Nitrat değerleri Şekil 3.9’da verilmiştir.

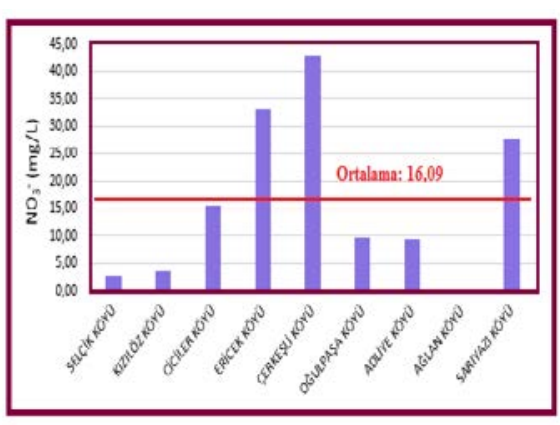

Şekil 3.9. Nitrat değerleri.

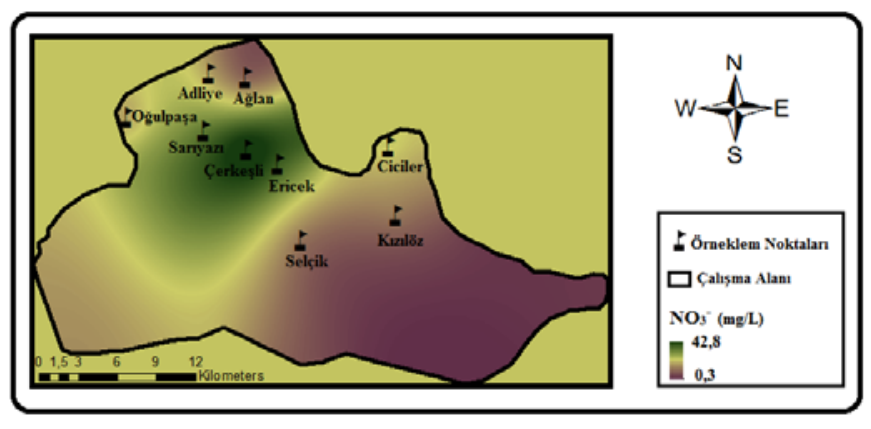

Şekil 3.10. Nitrat içeriklerinin mekânsal dağılımı.

Şekil 3.9'da da görüldüğü üzere en yüksek Nitrat değerine Çerkeşli Köyü’nün suyunda, en düşük Nitrat değerine ise Ağlan Köyü'nün suyunda rastlanmıştır. Osmaneli ilçesinde bulunan bütün köylerin Nitrat değerleri 50 mg/L’in altında olduğu için 'İnsani Tüketim Amaçlı Sular Hakkındaki Yönetmeliğe’ göre uygundur. Araştırma kapsamında değerlendirilen köylerdeki içme ve kullanma sularındaki nitrat içeriklerinin mekânsal olarak dağılımı Şekil 3.10’da verilmiştir. Nitrat değerlerinin analizi sonucunda Osmaneli ilçesinin orta kesimlerinde nitrat değerleri daha yüksekken, doğu ve kuzey kesimlerde değerler daha düşüktür.

\subsection{Klorür Değerlerinin Analizi}

Bilecik ili Osmaneli ilçesinde içme ve kullanma suyunda 20.11.2013 yılında 9 ayrı bölgeden (Selçik, Kızılöz, Ciciler, Ericek, Çerkeşli, Oğulpaşa, Adliye, Ağlan, Sarıyazı) alınan su numunelerindeki Klorür değerleri Şekil 3.11'de verilmiştir.

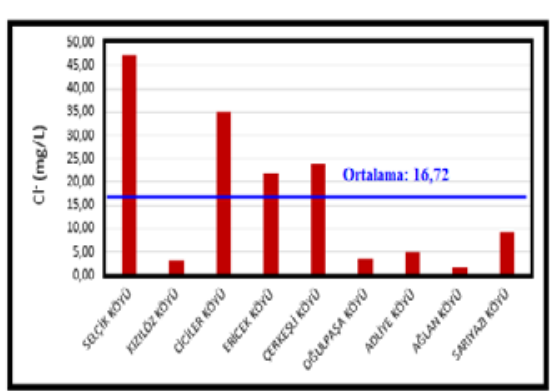

Şekil 3.11. Klorür değerleri.

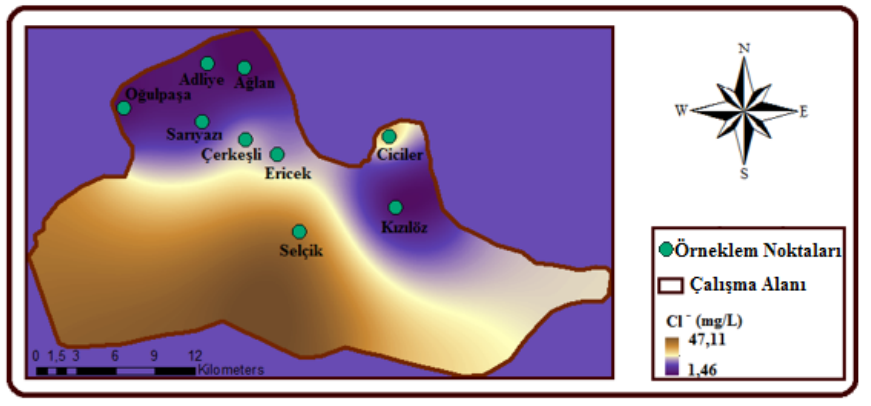

Şekil 3.12. Klorür içeriklerinin mekânsal dağılımı. 
Şekil 3.11'de belirtildiği üzere en yüksek Klorür değerine Selçik Köyü'nün suyunda, en düşük Klorür değerine ise Ağlan Köyü’nün suyunda rastlanmıştır. Osmaneli ilçesinde bulunan bütün köylerin içme ve kullanma suyundaki Klorür değerleri $250 \mathrm{mg} / \mathrm{L}$ 'den düşük olduğu için 'İnsani Tüketim Amaçlı Sular Hakkındaki Yönetmeliğe’ göre uygundur. Araştırma kapsamında değerlendirilen köylerdeki içme ve kullanma sularındaki klorür içeriklerinin mekânsal olarak dağı̆lımı Şekil 3.12'de verilmiştir. Klorür değerlerinin analizi sonucunda Osmaneli ilçesinin güney kesimlerinde klorür değerleri yüksekken, kuzey ve doğu kesimlerinde nispeten daha düşüktür.

\subsection{Sülfat Değerlerinin Analizi}

Bilecik ili Osmaneli ilçesinde içme ve kullanma suyunda 20.11.2013 yılında 9 ayrı bölgeden (Selçik, Kızılöz, Ciciler, Ericek, Çerkeşli, Oğulpaşa, Adliye, Ağlan, Sarıyazı) alınan su numunelerindeki Sülfat değerleri Şekil 3.13'de verilmiştir.

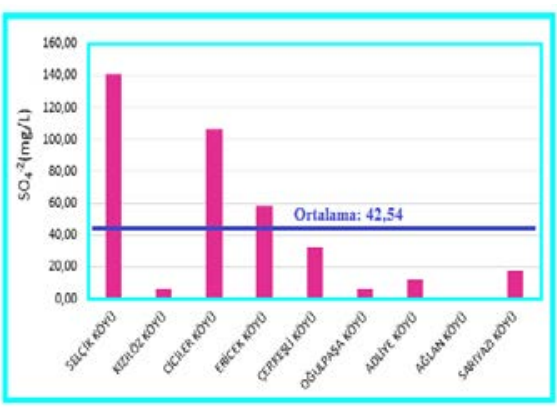

Şekil 3.13. Sülfat değerleri.

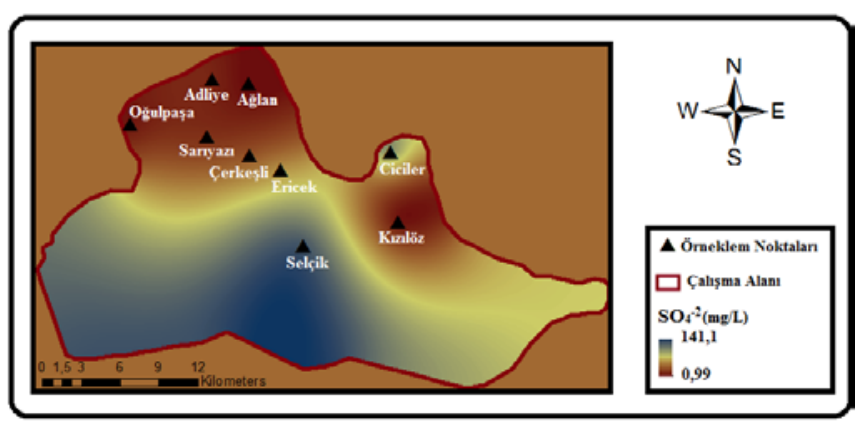

Şekil 3.14. Sülfat içeriklerinin mekânsal dağılımı.

Şekil 3.13’e göre en yüksek Sülfat değerine Selçik Köyü’nün suyunda, en düşük Sülfat değerine ise Ağlan Köyü’nün suyunda rastlanmıştır. Osmaneli ilçesinde bulunan bütün köylerin içme ve kullanma suyundaki Sülfat değerleri $250 \mathrm{mg} /$ L'den küçük olduğu için 'İnsani Tüketim Amaçlı Sular Hakkındaki Yönetmeliğe' göre uygundur. Araştırma kapsamında değerlendirilen köylerdeki içme ve kullanma sularındaki sülfat içeriklerinin mekânsal olarak dağılımı Şekil 3.14'de verilmiştir. Sülfat değerlerinin analizi sonucunda Osmaneli ilçesinin güney kısımlarında sülfat değerleri yüksekken, kuzey batı ve doğu kısımlarında daha düşüktür.

\subsection{Selenyum Değerlerinin Analizi}

Osmaneli ilçesinde bulunan bütün köylerin içme ve kullanma suyundaki Selenyum değerleri $4 \mu \mathrm{g} / \mathrm{L}$ ve ‘İnsani Tüketim Amaçlı Sular Hakkındaki Yönetmeliğge' göre $10 \mu \mathrm{g} / \mathrm{L}$ 'den küçük olduğu için uygundur.

\subsection{Arsenik Değerlerinin Analizi}

Bilecik ili Osmaneli ilçesinde içme ve kullanma suyunda 20.11.2013 yılında 9 ayrı bölgeden (Selçik, Kızılöz, Ciciler, Ericek, Çerkeşli, Oğulpaşa, Adliye, Ağlan, Sarıyazı) alınan su numunelerindeki Arsenik değerleri Şekil 3.15'de verilmiştir. 


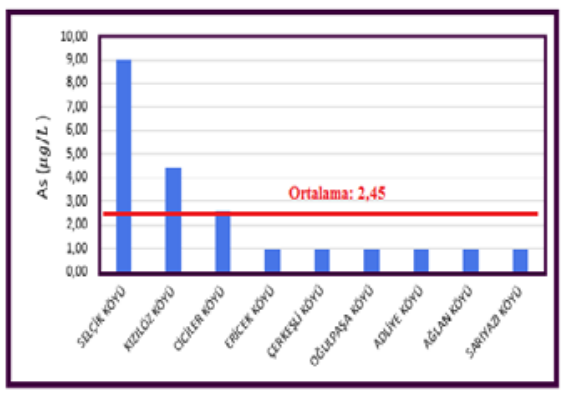

Şekil 3.15. Arsenik değerleri.

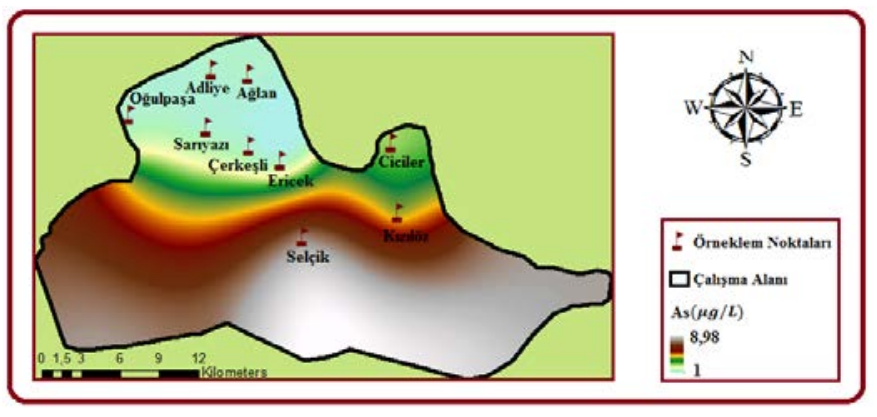

Şekil 3.16. Arsenik içeriklerinin mekânsal dağılımı.

Şekil 3.15’de görüldüğü üzere en yüksek arsenik değerine Selçik Köyü'nün suyunda, en düşük Arsenik değerine ise Sarıyazı, Ağlan, Adliye, Oğulpaşa, Çerkeşli ve Ericek Köylerinin sularında rastlanmıştır. Osmaneli ilçesinde bulunan bütün köylerin içme ve kullanma suyundaki Arsenik değerleri ‘İnsani Tüketim Amaçlı Sular Hakkındaki Yönetmeliğe’ göre $10 \mu \mathrm{g} / \mathrm{L}$ değerinin altında olduğu için uygun görülmektedir. Araştırma kapsamında değerlendirilen köylerdeki içme ve kullanma sularındaki arsenik içeriklerinin mekânsal olarak dağılımı Şekil 3.16'da verilmiştir. Arsenik değerlerinin analizi sonucunda Osmaneli ilçesinin güney kısımlarında arsenik miktarı daha fazla iken kuzey ve doğu kısımlarında daha düşük değerlerdedir.

\subsection{Alüminyum Değerlerinin Analizi}

Bilecik ili Osmaneli ilçesinde içme ve kullanma suyunda 20.11.2013 yılında 9 ayrı bölgeden (Selçik, Kızılöz, Ciciler, Ericek, Çerkeşli, Oğulpaşa, Adliye, Ağlan, Sarıyazı) alınan su numunelerindeki Alüminyum değerleri Şekil 3.17'de verilmiştir. Verilen şekilde en yüksek Alüminyum değerine Sarıyazı Köyü’nün suyunda rastlanmıştır. Diğer köylerin sularında Alüminyum değerleri düşük ve aynıdır. Osmaneli ilçesinde bulunan bütün köylerin içme ve kullanma suyundaki Alüminyum değerleri 'İnsani Tüketim Amaçlı Sular Hakkındaki Yönetmeliğe’ göre 200 g/L değerinden düşük olduğu için uygundur. Araştırma kapsamında değerlendirilen köylerdeki içme ve kullanma sularındaki alüminyum içeriklerinin mekânsal olarak dağılımı Şekil 3.18'de verilmiştir. Alüminyum değerlerinin analizi sonucunda Osmaneli ilçesinin kuzeybatı kesimlerinde daha yüksek alüminyum değerlerine, iç kısımlarda ise daha düşük değerlere rastlanmıştır.

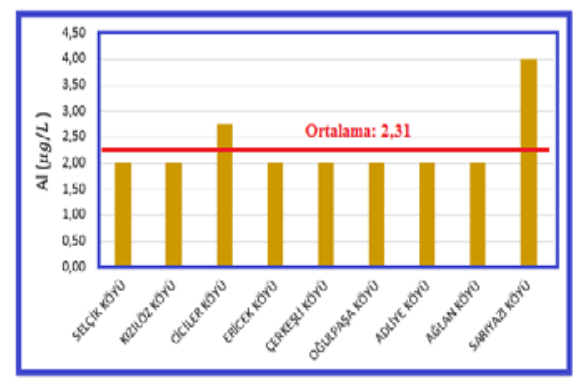

Şekil 3.17. Alüminyum değerleri.

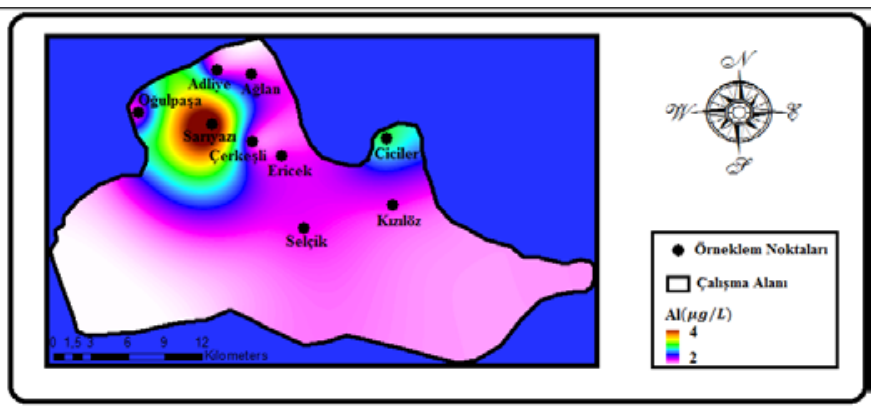

Şekil 3.18. Alüminyum içeriklerinin mekânsal dağılımı. 


\subsection{Bor Değerlerinin Analizi}

Bilecik ili Osmaneli ilçesinde içme ve kullanma suyunda 20.11.2013 yılında 9 ayrı bölgeden (Selçik, Kızılöz, Ciciler, Ericek, Çerkeşli, Oğulpaşa, Adliye, Ağlan,Sarıyazı) alınan su numunelerindeki Bor değerleri Şekil 3.19’da verilmiştir.

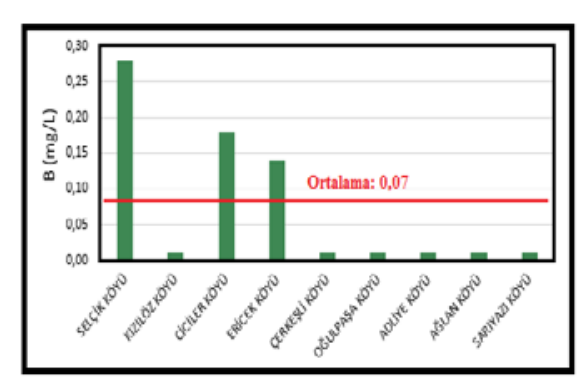

Şekil 3.19. Bor değerleri.

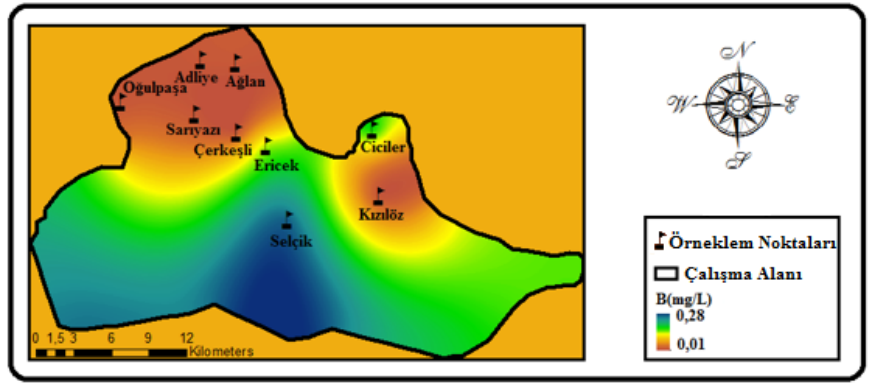

Şekil 3.20. Bor içeriklerinin mekânsal dağılımı.

Şekil 3.19’da en yüksek Bor değerine Selçik Köyü'nün suyunda, en düşük Bor değerine ise Kızılöz, Çerkeşli, Oğulpaşa, Adliye, Ağlan, Sarıyazı, Köyü’nün suyunda rastlanmıştır. Osmaneli ilçesinde bulunan bütün köylerin içme ve kullanma suyundaki Bor değerleri 'İnsani Tüketim Amaçlı Sular Hakkındaki Yönetmeliğe' göre $1 \mathrm{mg} / \mathrm{L}$ 'den daha düşük olduğu için uygundur. Araştırma kapsamında değerlendirilen köylerdeki İçme ve kullanma sularındaki bor içeriklerinin mekânsal olarak dağılımı Şekil 3.20’de verilmiştir. Bor değerlerinin analizi sonucunda Osmaneli ilçesinin güney kısımlarında bor miktarı daha yüksekken, kuzeybatı ve doğu kesimlerinde daha düşük miktarlardadır.

\subsection{Civa Değerlerinin Analizi}

Osmaneli ilçesinde bulunan bütün köylerin içme ve kullanma suyundaki Civa değerleri 1 g/L'dir. 'İnsani Tüketim Amaçlı Sular Hakkındaki Yönetmeliğe' göre $1 \mu \mathrm{g} / \mathrm{L}$ değerinden yüksek olmadığından uygundur. Tüm değerler $1 \mu \mathrm{g} / \mathrm{L}$ olduğundan CBS'de haritalaması yapılamamıştır.

\subsection{Demir Değerlerinin Analizi}

Osmaneli ilçesinde bulunan bütün köylerin içme ve kullanma suyundaki Demir değerleri $1 \mu$ g/L ve ‘İnsani Tüketim Amaçlı Sular Hakkındaki Yönetmeliğe’ göre 200 g/L değerinden düşük olduğundan uygundur. Tüm değerler $1 \mu \mathrm{g} / \mathrm{L}$ olduğundan CBS'de haritalaması yapılamamıştır.

\subsection{Krom Değerlerinin Analizi}

Bilecik ili Osmaneli ilçesinde içme ve kullanma suyunda 20.11.2013 yılında 9 ayrı bölgeden (Selçik, Kızılöz, Ciciler, Ericek, Çerkeşli, Oğulpaşa, Adliye, Ağlan, Sarıyazı) alınan su numunelerindeki Krom değerleri Şekil 3.21’de verilmiştir. 


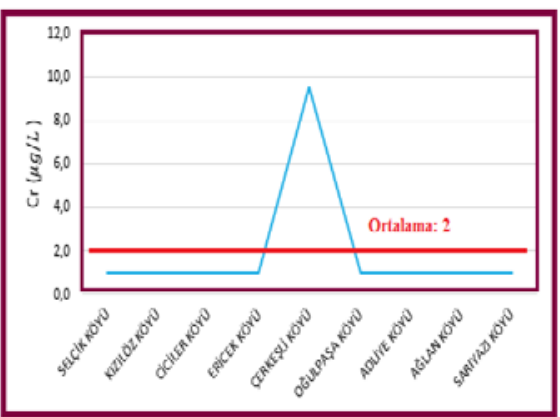

Şekil 3.21. Krom değerleri.

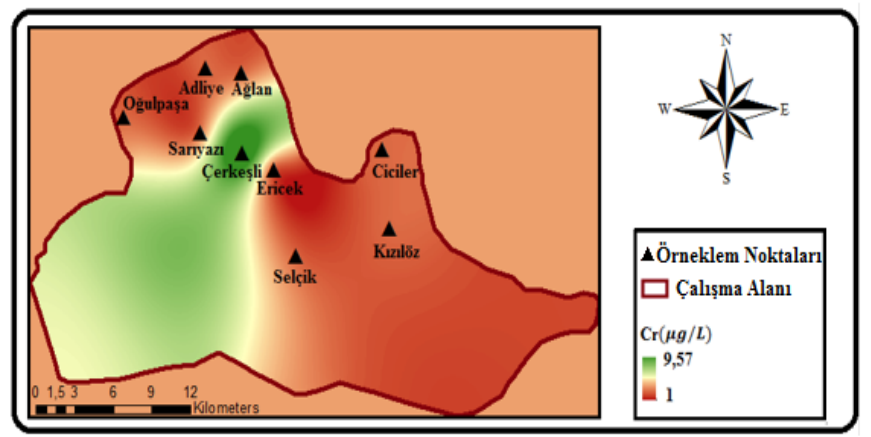

Şekil 3.22. Krom içeriklerinin mekânsal dağılımı.

Yukarıda verilen şekillerde de görüldüğü üzere en yüksek Krom değerine Çerkeşli Köyü’nün suyunda rastlanmıştır. Diğer köylerin sularında Krom değerleri düşük ve aynıdır. Osmaneli ilçesinde bulunan bütün köylerin içme ve kullanma suyundaki Krom değerleri 'İnsani Tüketim Amaçlı Sular Hakkındaki Yönetmeliğe’ göre $50 \mu \mathrm{g} / \mathrm{L}$ değerinin altında olduğu için uygundur. Araştırma kapsamında değerlendirilen köylerdeki içme ve kullanma sularındaki krom içeriklerinin mekânsal olarak dağılımı Şekil 3.22'de verilmiştir. Krom değerlerinin analizi sonucunda Osmaneli ilçesinde orta kesimlerde krom değerleri yüksekken, kuzeybatı ve doğuda daha düşük miktarlardadır.

\subsection{Kurşun Değerlerinin Analizi}

Osmaneli ilçesinde bulunan bütün köylerin içme ve kullanma suyundaki Kurşun değerleri $2 \mu \mathrm{g} / \mathrm{L}$ ve 'İnsani Tüketim Amaçlı Sular Hakkındaki Yönetmeliğe’ göre $10 \mu \mathrm{g} / \mathrm{L}$ 'den düşük olduğundan uygundur. Tüm değerler $2 \mu \mathrm{g} / \mathrm{L}$ olduğundan CBS'de haritalaması yapılamamıştır.

\subsection{Mangan Değerlerinin Analizi}

Bilecik ili Osmaneli ilçesinde içme ve kullanma suyunda 20.11.2013 yılında 9 ayrı bölgeden (Selçik, Kızılöz, Ciciler, Ericek, Çerkeşli, Oğulpaşa, Adliye, Ağlan, Sarıyazı) alınan su numunelerindeki Mangan değerleri Şekil 3.23'de verilmiştir.

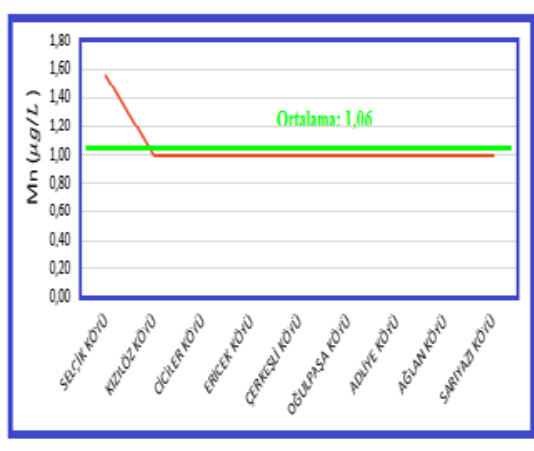

Şekil 3.23. Mangan değerleri.

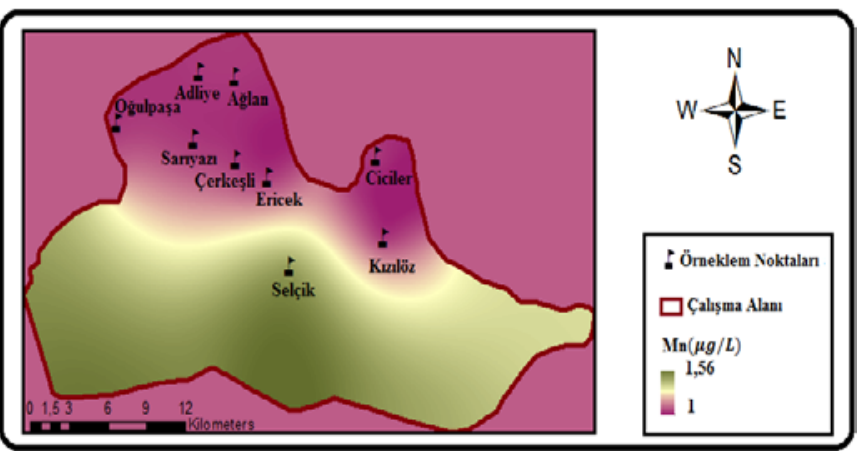

Şekil 3.24. Mangan içeriklerinin mekânsal dağılımı.

Verilen şekilde (Şekil 3.23) en yüksek Mangan değerine Selçik Köyü’nün suyunda rastlanmıştır. Diğer köylerin sularında Mangan değerleri düşük ve aynıdır. Osmaneli ilçesinde bulunan bütün köylerin içme ve kullanma suyundaki Mangan değerleri ‘'̇nsani Tüketim Amaçlı Sular Hakkındaki Yönetmeliğe’ göre $50 \mu \mathrm{g} / \mathrm{L}$ değerinden düşük olduğundan uygundur. Araştırma kapsamında değerlendirilen köylerdeki 
içme ve kullanma sularındaki mangan içeriklerinin mekânsal olarak dağılımı Şekil 3.24'de verilmiştir. Mangan değerlerinin analizi sonucunda Osmaneli ilçesinin güney kısımlarında değerler daha yüksekken kuzey kısımlarda daha düşüktür.

\subsection{Nikel Değerlerinin Analizi}

Bilecik ili Osmaneli ilçesinde içme ve kullanma suyunda 20.11.2013 yılında 9 ayrı bölgeden (Selçik, Kızılöz, Ciciler, Ericek, Çerkeşli, Oğulpaşa, Adliye, Ağlan, Sarıyazı) alınan su numunelerindeki Nikel değerleri Şekil 3.25'de verilmiştir.

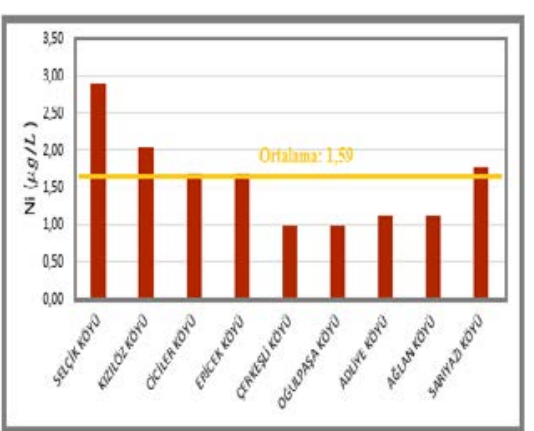

Şekil 3.25. Nikel değerleri.

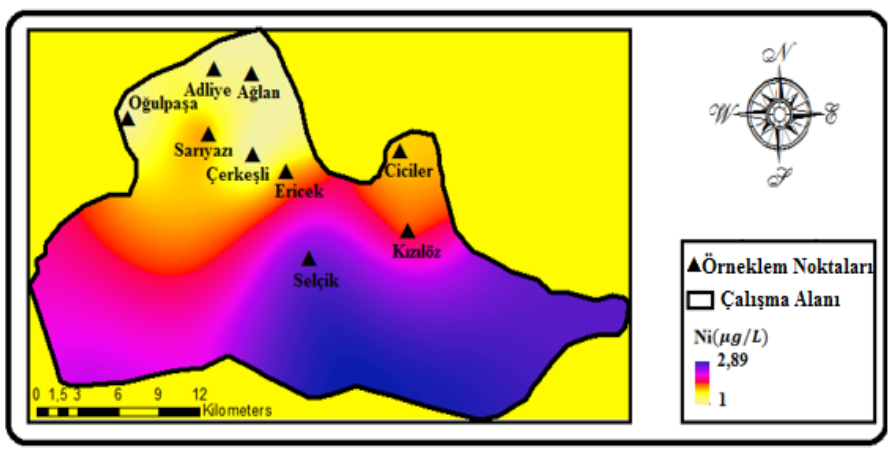

Şekil 3.26. Nikel içeriklerinin mekânsal dağılımı.

Verilen şekilde (Şekil 3.25) en yüksek Nikel değerine Selçik Köyü’nün suyunda, en düşük Nikel değerine ise Çerkeşli ve Oğulpaşa Köyü'nün suyunda rastlanmıştır. Osmaneli ilçesinde bulunan bütün köylerin içme ve kullanma suyundaki Nikel değerleri 'İnsani Tüketim Amaçlı Sular Hakkındaki Yönetmeliğe’ göre 20 g/L değerinde düşük olduğu için uygundur. Araştırma kapsamında değerlendirilen köylerdeki içme ve kullanma sularındaki nikel içeriklerinin mekânsal olarak dağılımı Şekil 3.26'da verilmiştir. Nikel değerlerinin analizi sonucunda Osmaneli ilçesinin güneydoğu kesimlerinde nikel değerleri daha yüksekken, kuzeybatı kesimlerinde daha düşüktür.

\subsection{Sodyum Değerlerinin Analizi}

Bilecik ili Osmaneli ilçesinde içme ve kullanma suyunda 20.11.2013 yılında 9 ayrı bölgeden (Selçik, Kızılöz, Ciciler, Ericek, Çerkeşli, Oğulpaşa, Adliye, Ağlan, Sarıyazı) alınan su numunelerindeki Sodyum değerleri Şekil 3.27'de verilmiştir.

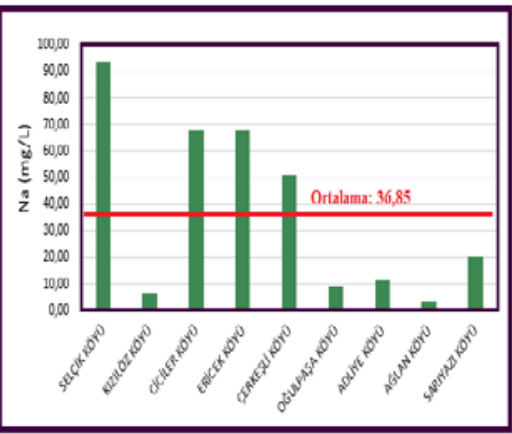

Şekil 3.27. Sodyum değerleri.

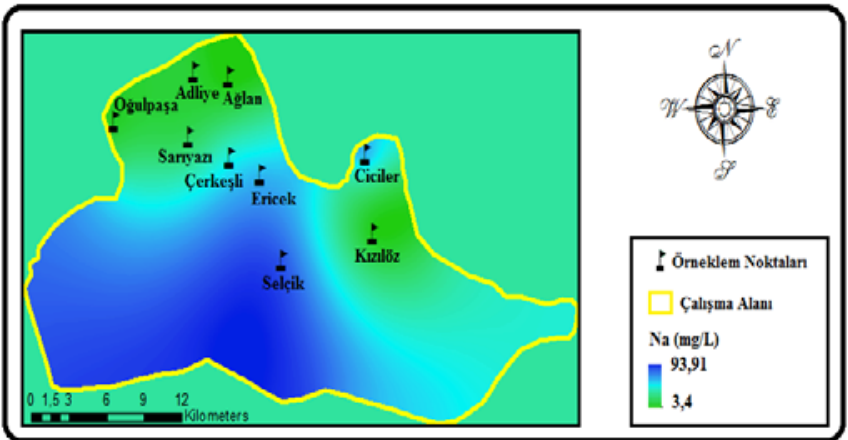

Şekil 3.28. Sodyum içeriklerinin mekânsal dağılımı. 
Şekil 3.27’de görüldüğü üzere en yüksek Sodyum değerine Selçik Köyü'nün suyunda, en düşük Sodyum değerine ise Ağlan Köyü'nün suyunda rastlanmıştır. Osmaneli ilçesinde bulunan bütün köylerin içme ve kullanma suyundaki Sodyum değerleri İnsani Tüketim Amaçlı Sular Hakkındaki Yönetmeliğe göre $200 \mathrm{mg} / \mathrm{L}$ değerinden düşük olduğundan uygundur. Araştırma kapsamında değerlendirilen köylerdeki içme ve kullanma sularındaki sodyum içeriklerinin mekânsal olarak dağılımı Şekil 3.28'de verilmiştir. Sodyum değerlerinin analizi sonucunda Osmaneli ilçesinin orta ve güney kısımlarında sodyum değerleri yüksekken, kuzeybatı ve doğu tarafında daha düşüktür.

\section{Tartışma ve Sonuç}

Günümüzde hızla artan nüfus, su kaynaklarının kirlenmesine ve tükenmesine yol açmaktadır. Canlıların vazgeçilmezi olan su için gerekli koruma ve tedbirlerin alınması gün geçtikçe önem kazanmaktadır. Su kalitesi yönetim sistemlerinde özellikle son yıllarda Coğrafi Bilgi Sistemleri (CBS) yaygın bir biçimde kullanılmaya başlanmıştır $[10,11]$. Bu çalışmada da; Bilecik ili Osmaneli ilçesinin içme ve kullanma suyu kalitesinin CBS ile konumsal analizi ve tematik haritalandırılması yapılmışır. 9 farklı noktadan alınan 20 farklı analiz sonucuna göre Osmaneli ilçesinin içme ve kullanma suyu 'İnsani Tüketim Amaçlı Sular Hakkında Yönetmeliğe' göre incelenmiştir. Yapılan incelemede aşağıdaki sonuçlara ulaşı1mıştır.

Osmaneli ilçesinde bulunan bütün köylerin içme kullanma suyundaki pH değerleri ‘'̇nsani Tüketim Amaçlı Sular Hakkındaki Yönetmeliğe’ göre 6.5-9.5 değerleri arasında olduğu için uygundur. pH değerlerinin analiz sonuçlarına göre; Osmaneli ilçesinin kuzey batı kesimindeki köylerde en yüksek değere rastlanmıştır. İç ve orta kısımlarda $\mathrm{pH}$ değerleri nispeten daha düşüktür. İletkenlik değerleri 'İnsani Tüketim Amaçlı Sular Hakkındaki Yönetmeliğe' göre, $2500 \mu \mathrm{S} / \mathrm{cm}$ 'den düşük olduğu için uygundur. İletkenlik değerlerinin analiz sonuçlarına göre; Osmaneli ilçesinin kuzey kesimlerinde iletkenlik değerleri düşükken, iç ve güney kesimlere doğru daha yüksektir. Oksitlenebilirlik değerleri 5 mg/L'den küçük olduğu için 'İnsani Tüketim Amaçlı Sular Hakkındaki Yönetmeliğe' göre uygundur. Oksitlenebilirlik değerlerinin analizi sonucunda Osmaneli ilçesinde orta ve doğu kısımlardaki oksitlenebilirlik değerleri kısmen daha düşükken, batıda özellikle Oğulpaşa köyünde oksitlenebilirlik değeri daha yüksektir. Amonyum değerleri $0,03 \mathrm{mg} / \mathrm{L}$ ve 'İnsani Tüketim Amaçlı Sular Hakkındaki Yönetmeliğe' göre $0,50 \mathrm{mg} / \mathrm{L}$ 'den düşük olduğu için uygundur. Tüm değerler $0,03 \mathrm{mg} / \mathrm{L}$ olduğundan CBS'de haritalaması yapılamamıştır. Florür değerleri 'İnsani Tüketim Amaçlı Sular Hakkındaki Yönetmeliğe' göre 1,5 mg/ L'den küçük olduğu için uygundur. Florür değerlerinin analizi sonucunda Osmaneli ilçesinin orta kısımlarında bulunan Ericek köyünde değerler daha yüksekken diğer kısımlarda nispeten daha düşüktür. Nitrit değerleri $0,03 \mathrm{mg} / \mathrm{L}$ ve 'İnsani Tüketim Amaçlı Sular Hakkındaki Yönetmeliğe2 göre $0,50 \mathrm{mg} / \mathrm{L}$ 'den düşük olduğundan uygundur. Tüm değerler $0.03 \mathrm{mg} / \mathrm{L}$ olduğunan CBS'de haritalaması yapılamamıştır. Nitrat değerleri $50 \mathrm{mg} / \mathrm{L}$ 'in altında olduğu için 'İnsani Tüketim Amaçlı Sular Hakkındaki Yönetmeliğe' göre uygundur. Nitrat değerlerinin analizi sonucunda Osmaneli ilçesinin orta kesimlerinde nitrat değerleri daha yüksekken, doğu ve kuzey kesimlerde değerler daha düşüktür. Klorür değerleri $250 \mathrm{mg} / \mathrm{L}$ 'den düşük olduğu için 'İnsani Tüketim Amaçlı Sular Hakkındaki Yönetmeliğe' göre uygundur. Klorür değerlerinin analizi sonucunda Osmaneli ilçesinin güney kesimlerinde klorür değerleri yüksekken, kuzey ve doğu kesimlerinde nispeten daha düşüktür. Sülfat 
değerleri 250 mg /L'den küçük olduğu için ‘İnsani Tüketim Amaçlı Sular Hakkındaki Yönetmeliğe’ göre uygundur. Sülfat değerlerinin analizi sonucunda Osmaneli ilçesinin güney kısımlarında sülfat değerleri yüksekken, kuzey batı ve doğu kısımlarında daha düşüktür. Selenyum değerleri $4 \mu g / L$ ve 'İnsani Tüketim Amaçlı Sular Hakkındaki Yönetmeliğe’ göre $10 \mu \mathrm{g} / \mathrm{L}$ 'den küçük olduğu için uygundur. Tüm değerler $4 \mu \mathrm{g} / L$ olduğundan CBS'de haritalama yapılamamıştır. Arsenik değerleri 'İnsani Tüketim Amaçlı Sular Hakkındaki Yönetmeliğe’ göre 10 pg/L değerinin altında olduğu için uygun görülmektedir. Arsenik değerlerinin analizi sonucunda Osmaneli ilçesinin güney kısımlarında arsenik miktarı daha fazla iken kuzey ve doğu kısımlarında daha düşük değerlerdedir. Alüminyum değerleri ‘İnsani Tüketim Amaçlı Sular Hakkındaki Yönetmeliğe' göre $200 \mu \mathrm{g} / \mathrm{L}$ değerinden düşük olduğu için uygundur. Alüminyum değerlerinin analizi sonucunda Osmaneli ilçesinin kuzeybatı kesimlerinde daha yüksek alüminyum değerlerine, iç kısımlarda ise daha düşük değerlere rastlanmıştır. Bor değerleri 'İnsani Tüketim Amaçlı Sular Hakkındaki Yönetmeliğe' göre $1 \mathrm{mg} / \mathrm{L}$ 'den daha düşük olduğu için uygundur. Bor değerlerinin analizi sonucunda Osmaneli ilçesinin güney kısımlarında bor miktarı daha yüksekken, kuzeybatı ve doğu kesimlerinde daha düşük miktarlardadır. Civa değerleri $1 \mu \mathrm{g} / \mathrm{L}$ 'dir. 'İnsani Tüketim Amaçlı Sular Hakkındaki Yönetmeliğe’ göre $1 \mu \mathrm{g} / \mathrm{L}$ değerinden yüksek olmadığından uygundur. Tüm değerler $1 \mu \mathrm{g} / \mathrm{L}$ olduğundan CBS'de haritalama yapılamamıştır. Demir değerleri $1 \mu \mathrm{g} / \mathrm{L}$ ve 'İnsani Tüketim Amaçlı Sular Hakkındaki Yönetmeliğe’ göre $200 \mu \mathrm{g} / \mathrm{L}$ değerinden düşük olduğundan uygundur. Tüm değerler $1 \mu \mathrm{g} / \mathrm{L}$ olmasından dolayı CBS'de haritalama yapılamamıştır. Krom değerleri 'İnsani Tüketim Amaçlı Sular Hakkındaki Yönetmeliğe’ göre $50 \mu \mathrm{g} / \mathrm{L}$ değerinin altında olduğu için uygundur. Krom değerlerinin analizi sonucunda Osmaneli ilçesinde orta kesimlerde krom değerleri yüksekken, kuzeybatı ve doğuda daha düşük miktarlardadır. Kurşun değerleri $2 \mu \mathrm{g} / \mathrm{L}$ ve 'İnsani Tüketim Amaçlı Sular Hakkındaki Yönetmeliğe' göre $10 \mu \mathrm{g} / \mathrm{L}$ 'den düşük olduğundan uygundur. Tüm değerler $2 \mu \mathrm{g} / \mathrm{L}$ olduğundan CBS'de haritalama yapılamamıştır. Mangan değerleri 'İnsani Tüketim Amaçlı Sular Hakkındaki Yönetmeliğe' göre $50 \mu \mathrm{g} / \mathrm{L}$ değerinden düşük olduğundan uygundur. Mangan değerlerinin analizi sonucunda Osmaneli ilçesinin güney kısımlarında değerler daha yüksekken kuzey kısımlarda daha düşüktür. Nikel değerleri ‘İnsani Tüketim Amaçlı Sular Hakkındaki Yönetmeliğe’ göre $20 \mu \mathrm{g} / \mathrm{L}$ değerinde düşük olduğu için uygundur. Nikel değerlerinin analizi sonucunda Osmaneli ilçesinin güneydoğu kesimlerinde nikel değerleri daha yüksekken, kuzeybatı kesimlerinde daha düşüktür. Sodyum değerleri 'İnsani Tüketim Amaçlı Sular Hakkındaki Yönetmeliğe’ göre 200 mg/L değerinden düşük olduğundan uygundur. Sodyum değerlerinin analizi sonucunda Osmaneli ilçesinin orta ve güney kısımlarında sodyum değerleri yüksekken, kuzeybatı ve doğu tarafında daha düşüktür.

Tespit edilen sonuçlara göre Osmaneli ilçesinin içme ve kullanma sularındaki pH, iletkenlik, oksitlenebilirlik, amonyum, florür, nitrit, nitrat, klorür, sülfat, selenyum, arsenik, alüminyum, bor, civa, demir, krom, kurşun, mangan, nikel, sodyum değerleri 'İnsani Tüketim Amaçlı Sular Hakkında Yönetmeliğe' göre uygun değerlerdedir.

\section{Teşekkür}

Bu çalışmada Bursa Valiliği İl Sağlık Müdürlüğü Halk Sağlığı Laboratuarının verileri kullanılmıştır. Ayrıca çalışma 15- 17 Mayıs 2017 tarihlerinde Nevşehir-Kapadokya'da düzenlenen 
'International Conference on Agriculture, Forest, Food Sciences and Technologies (ICAFOF-2017)' konferansında sunulmuş ve bildiriler kitabında özet olarak yer almıştır.

\section{Kaynaklar}

[1] Foyrap, A., 'Erzurum İlinde Yapılan Sulama Amaçlı Göletlerin Durumu, Yeterlilikleri ve Sorunları Üzerine Bir Araştırma', Erzurum, 1992.

[2] Barlas, M., 'Akarsu Kirlenmesinin Biyolojik ve Kimyasal Yönden Değerlendirilmesi ve Kriterleri’, Doğu Anadolu Bölgesi I. Ve II. Su Ürünleri Sempozyumu, Erzurum, 1995.

[3] Kazancı, N., Girgin, S., Dügel, M., ve Oğuzkurt, D., 'Akarsuların Çevre Kalitesi Yönünden Değerlendirlmesinde ve İzlenmesinde Biyotik İndeks Yöntemi’, Ankara, 1997.

[4] Tepe, Y., Boyd, C. E., 'Sediment Quality in Arkansas Bait Fish Minnows Ponds', Journal of World Aquaculture Society, 33(3), 2002.

[5] Taş, B. 'Derbent Baraj Gölü (Samsun) Su Kalitesinin İncelenmesi, Ekoloji, 15, 2006.

[6] Aydın, D., 'İçme Suyu Dağıtım Sistemlerinde CBS Tabanlı Su Kalitesi Yönetimi', Yayınlanmamış Doktora Tezi, İstanbul Teknik Üniversitesi Fen Bilimleri Enstitüsü Çevre Mühendisliği Anabilim Dalı, İstanbul, 2007.

[7] Sönmez, N. K., Sarı, M., 'Coğrafi Bilgi Sistemleri Temel Esasları ve Uygulama Alanları’, 2004.

[8] Susam, T., Karaman, S., Öztekin, T., 'Yüzey Suları Coğrafi Bilgi Sistemi; Tokat İli Örneği', Gaziosmanpaşa Üniversitesi Ziraat Fakültesi Dergisi, 1, 2006.

[9] Çalışma alanının yeri ve konumu-http://www.haritatr.com/osmaneli-haritasi-i96.

[10] Kalıpcı, E., Cüce. H., Toprak, S. "Damsa Barajı (Nevşehir) Yüzey Suyu Kalitesinin Coğrafi Bilgi Sistemi İle Mekansal Analizi", Karaelmas Fen ve Mühendislik Dergisi, 7(1), 312-319, 2017.

[11] Kalıpcı, E., Cüce. H., Toprak, S. "Coğrafi Bilgi Sistemleri (CBS) Kullanılarak Mamasın Barajı Yüzey Suyu Kalitesinin Değerlendirilmesi", Ömer Halisdemir Üniversitesi Mühendislik Bilimleri Dergisi, 6(2), 351-361, 2017. 